\title{
The biological effects and digestible energy value of a sugar-beet fibre preparation in the rat
}

\author{
BY I. T. JOHNSON, G. LIVESEY, J. M. GEE, J. C. BROWN AND G. M. WORTLEY \\ Department of Nutrition and Food Quality, Institute of Food Research, Norwich Laboratory, \\ Colney Lane, Norwich NR4 $7 U A$
}

(Received 10 May 1989 - Accepted 2 February 1990)

\begin{abstract}
A sugar-beet fibre preparation (SBF) was incorporated into a semi-synthetic rat diet at a level of $100 \mathrm{~g} / \mathrm{kg}$. The material caused no feed aversion, and gain of live weight was unimpaired. SBF appeared to be slightly more fermentable than wheat bran and only marginally less effective as a faecal bulking agent when compared with equalized intakes of non-starch polysaccharide. SBF did not stimulate mucosal cell turnover in the small intestine. Some enlargement of the caecum was observed in animals given SBF, but it was no greater than that of animals given wheat bran. Animals given SBF had a lower serum cholesterol concentration than both the fibre-free controls and those given wheat bran. This hypocholesterolaemic effect was less than that of guar gum however. The partial digestibility of energy for SBF was 0.64 , and its partial digestible energy value was $11.3 \mathrm{~kJ}(2.7 \mathrm{kcal}) / \mathrm{g}$. The partial digestibility of energy for non-starch polysaccharide in SBF was estimated to be 0.53 and its partial digestible energy value was $9.1 \mathrm{~kJ}(2.2 \mathrm{kcal}) / \mathrm{g}$. This value was not significantly different from that expected for unavailable carbohydrate in mixed human diets.
\end{abstract}

Sugar-beet fibre: Dietary fibre: Digestible energy: Rat

Dietary fibre is a general term used to describe a variety of plant polysaccharides which share the common property of resistance to mammalian digestive enzymes (Trowell et al. 1976). These materials differ considerably, both in their physical and chemical properties, and in their biological effects (Selvendran et al. 1987). Some forms of dietary fibre, notably the cereal brans, are thought to exert beneficial effects in the gastrointestinal tract, where they increase both faecal dry bulk and water content (Findlay et al. 1974). The soluble fibre components such as pectin, oat gum and some of the constituents of legumes are associated with reduced post-prandial glycaemia (Jenkins et al. 1978) and reduced plasma cholesterol levels in human subjects (Judd \& Truswell, 1982; Anderson et al. 1984).

The purpose of the present study was to investigate the biological properties of a commercial isolate from sugar beet (Beta Fibre; SBF), which is rich in both soluble and insoluble non-starch polysaccharides. The aim was to assess the potential value of the material as a faecal bulking agent, together with its effect on various physiological variables, including plasma cholesterol level, in the ad lib.-fed rat. For comparative purposes the study also included wheat bran and guar gum.

A second objective was to determine the partial digestible energy value (energy conversion factor) of the material. For this purpose, a controlled-intake, long-term dietary energy balance protocol was used, which gives low coefficients of variation for the measurement of apparent digestibility of gross energy and, hence, can be used to obtain precise information on energy value. 


\section{MATERIALS AND METHODS}

\section{Animals and diets}

Male Wistar rats (approximately $135 \mathrm{~g}$ ) were purchased from a commercial supplier and housed in wire-bottomed cages in an animal house $\left(21^{\circ}\right)$ with $12 \mathrm{~h}$ light $-12 \mathrm{~h}$ dark cycle.

The compositions of the semi-synthetic, powdered diets are shown in Table 1. For the physiological study, $100 \mathrm{~g}$ of each source of dietary fibre was substituted for an equal quantity of maize starch. However, for the digestible energy study, either a basal diet was given or the basal diet was supplemented with $100 \mathrm{~g} \mathrm{SBF} / \mathrm{kg}$ basal diet. The SBF, Beta Fibre, was manufactured and supplied by British Sugar plc, Peterborough. The total nonstarch polysaccharide content was $750 \mathrm{~g} / \mathrm{kg}$, as determined by the modified Englyst technique (Englyst \& Cummings, 1984). The material also contained $17 \mathrm{~g}$ lignin $/ \mathrm{kg}$ and $42 \mathrm{~g}$ ash $/ \mathrm{kg}$. The wheat bran was a commercial preparation for human consumption purchased locally from J. Sainsbury plc, and guar gum was obtained from Sigma (Poole, Dorset).

\section{Physiological study}

Animals were caged in pairs and given the fibre-free diet (FF1) for an acclimation period of $4 \mathrm{~d}$ after arrival. Forty animals were then allocated randomly to four groups of ten, each of which was given diet FF1 or the guar gum- or wheat bran- or SBF-supplemented diets ad lib. for $28 \mathrm{~d}$.

Food and water intakes were assessed on a daily basis during the first and final $7 \mathrm{~d}$ of the feeding period and continuously between days 7 and 21 . Body-weight was monitored approximately every $3-4 \mathrm{~d}$ throughout the study period. Faecal pellets were collected on days $21-28$ and separated from spilled food, dried overnight at $85^{\circ}$ and weighed. The wet weight of faeces was calculated from the moisture contents of freshly voided faecal pellets collected immediately before killing the rats at the end of the study.

On the first morning immediately following the end of the feeding period, rats in each group were give intraperitoneal injections of the antimitotic alkaloid vincristine, dissolved in distilled water $(1 \mathrm{mg} / \mathrm{kg})$. The animals were then killed at $12 \mathrm{~min}$ intervals by intraperitoneal injection of phenobarbitone (Euthatal; May \& Baker, Dagenham, Essex) followed by cervical dislocation. The abdomen was opened with a mid-ventral incision, a blood sample (about $5 \mathrm{ml}$ ) was taken from the posterior vena cava, and divided equally between tubes containing either aprotinin (Sigma; 0.1 mg) and NaEDTA (15 mg), or no anticoagulent. The $\mathrm{pH}$ of the caecal contents was measured by insertion of a semi-micro $\mathrm{pH}$ electrode through an incision in the caecum before removal of the small and large intestines.

The length of the small intestine was measured after being extended gently on the bench. A segment of intestine (about $5 \mathrm{~mm}$ ) was removed from the distal ileum at a point $95 \%$ of the total small intestinal length from the gastro-duodenal junction, and placed in fixative (alcohol-acetic acid, $75: 25, \mathrm{v} / \mathrm{v}$ ). The caecum was weighed full and then emptied of contents. A representative sample (about $0.75 \mathrm{mg}$ ) of mixed caecal contents was placed in a preweighed vial, oven-dried $\left(85^{\circ}\right)$ overnight and reweighed. The caecal tissue was then gently rinsed free of contents, blotted to remove excess water, weighed, oven-dried and reweighed.

Plasma samples $(1 \mathrm{ml})$ were stored at $-20^{\circ}$ after addition of further aprotinin. Total plasma glucagon-like immunoreactivity was assayed using a commercial radioimmunoassay kit containing antisera reactive to total glucagon (Novo Laboratories Ltd, Basingstoke, Hants). Samples of serum were also stored at $-20^{\circ}$ before total cholesterol levels were measured using a commercial assay system (CHD-PAP, C-System; Boehringer).

The proliferation of small intestinal mucosal cells was measured by the metaphase-arrest technique (Clark, 1970). Sub-samples of fixed tissue were passed through ethanol-water 
Table 1. Composition of experimental diets $(g)$

\begin{tabular}{|c|c|c|c|c|c|c|}
\hline \multirow[b]{2}{*}{ Ingredients } & \multicolumn{4}{|c|}{ Physiological study } & \multicolumn{2}{|c|}{ Digestible energy study } \\
\hline & $\begin{array}{c}\text { Fibre-free } \\
\text { (I) }\end{array}$ & Wheat bran & Guar gum & $\begin{array}{l}\text { Sugar-beet } \\
\text { fibre } \\
\text { (1) }\end{array}$ & $\begin{array}{c}\text { Fibre-free } \\
\text { (2) }\end{array}$ & $\begin{array}{c}\text { Sugar-beet } \\
\text { fibre } \\
\text { (2) }\end{array}$ \\
\hline Maize starch & 360 & 260 & 260 & 260 & 330 & 330 \\
\hline Sucrose & 300 & 300 & 300 & 300 & 330 & 330 \\
\hline Casein & 200 & 200 & 200 & 200 & 200 & 200 \\
\hline Maize oil & 80 & 80 & 80 & 80 & 80 & 80 \\
\hline Mineral mix* & 40 & 40 & 40 & 40 & 40 & 40 \\
\hline Vitamin mix $\uparrow$ & 20 & 20 & 20 & 20 & 20 & 20 \\
\hline DL-Methionine & - & -- & - & - & $2 \cdot 5$ & $2 \cdot 5$ \\
\hline Wheat bran & $\ldots$ & 100 & - & - & - & - \\
\hline Guar gum & - & - & 100 & - & - & - \\
\hline Sugar-beet fibre & - & - & - & 100 & - & 100 \\
\hline Total wt of diet (g) & 1000 & 1000 & 1000 & 1000 & $1002 \cdot 5$ & 1002.5 \\
\hline
\end{tabular}

* Provided the following levels of minerals in the finished diets $(\mathrm{g} / \mathrm{kg}): \mathrm{CaHPO}_{4} 13, \mathrm{CaCO}_{3} 8 \cdot 2, \mathrm{KCl} 7.03$, $\mathrm{Na}_{2} \mathrm{HPO}_{4} 7 \cdot 4, \mathrm{MgSO}_{4} . \mathrm{H}_{2} \mathrm{O} 4 \cdot 0, \mathrm{MnSO}_{4} . \mathrm{H}_{2} \mathrm{O} 0 \cdot 18, \mathrm{ZnCO}_{3} 0 \cdot 1, \mathrm{FeSO}_{4} .7 \mathrm{H}_{2} \mathrm{O} 0.144, \mathrm{CuSO}_{4} 0.015, \mathrm{KIO}_{3} 0 \cdot 001$.

$\dagger$ Provided the following levels of vitamins in the finished diets $(\mathrm{mg} / \mathrm{kg})$ : nicotinic acid 60 , cyanocobalamin in mannitol 50, calcium-1)-pantothenate 40 , thiamin hydrochloride 10 , riboflavin 10 , pteroylmonoglutamic acid 5 , Dbiotin 1, vitamin K 1, Rovimix E-25 (Roche) 300, Rovimix A-500 (Roche) 25, Rovimix A-500 1D 3 (Roche) 15. choline bitartrate 1800 ; in maize starch 17680 .

$(50: 50, \mathrm{v} / \mathrm{v})$, stained in bulk with Feulgen's reagent, rinsed in distilled water and transferred to glacial acetic acid-water $(45: 55, \mathrm{v} / \mathrm{v})$. Ten crypts were obtained from each sample by microdissection, transferred to a microscope slide and flattened gently beneath a coverslip. The numbers of blocked metaphases per crypt were counted under a compound microscope and the mean for ten individual crypts was calculated. The crypt-cell production rate was estimated as the slope of the linear regression line obtained after plotting the number of blocked metaphases per crypt for each rat $v$. the time interval from administration of vincristine to death.

\section{Digestible energy study}

Twenty animals were housed singly in wire-bottomed cages and received for a period of $14 \mathrm{~d}$ a controlled quantity $(10 \mathrm{~g} / \mathrm{d}$ per rat) of a semi-synthetic basal diet, free of non-starch polysaccharides (FF2; Table 1). The animals were then randomly allocated to two dietary groups of ten. One group continued to receive FF2, the other group was given the same diet supplemented with the SBF $(100 \mathrm{~g} / \mathrm{kg}$ basal diet). The unsupplemented (FF2) and the supplemented (SBF2) dietary groups were fed at rates of 10 and $11 \mathrm{~g} / \mathrm{rat}$ per $\mathrm{d}$ respectively, at about 10.00 hours each day for the next $28 \mathrm{~d}$. Animals were weighed periodically to ensure food intake was above maintenance requirements. Food intake and spillage were recorded daily, but the latter was usually negligible. Faeces were collected daily from absorbant paper placed under the cage to minimize contamination of faeces with urine. Faecal collections were stored at $-20^{\circ}$ before freeze-drying and analysis. Samples of food were taken during the $28 \mathrm{~d}$ balance periods for immediate moisture determination. The balance period began at 10.00 hours on day 1 and finished at 10.00 hours on day 29 . All animals received water $a d$ lib.

The moisture contents of samples of diets and SBF, sampled at the time of diet preparation, were determined by weighing (approximately $2 \mathrm{~g}$ ) before and after drying to constant weight in a Metler 4816 infra-red drier at $85^{\circ}$. Dry weights of faeces produced over the $28 \mathrm{~d}$ balance period were determined by weighing after freeze-drying. 
Bomb calorimetry was performed on dry food and faecal samples. To prepare faeces for calorimetry, the freeze-dried samples were each ground to a powder and thoroughly mixed. Samples $(0.5 \mathrm{~g})$ for calorimetry were re-dried and re-weighed. A Gallenkamp Adiabatic Bomb Calorimeter and benzoic acid thermochemical standard were used. The gross energy value of the $\mathrm{SBF}$ isolate was determined directly by bomb calorimetry.

The partial digestible energy value $\left(\mathrm{DE}_{\mathrm{s}}\right.$ ) of the $\mathrm{SBF}$ was calculated as follows (Livesey, $1989 b, 1990)$ :

$$
\begin{gathered}
\mathrm{DE}_{\mathrm{s}}=\mathrm{GE}_{\mathrm{s}}(1-S), \\
S=\frac{\mathrm{D}_{\mathrm{ffd}}-\mathrm{D}_{\text {sbd }}}{\mathrm{E}_{\mathrm{s}} / \mathrm{E}_{\mathrm{sbd}}},
\end{gathered}
$$

where $G_{s}$ is the gross energy value $\left(\mathrm{kJ} / \mathrm{g}\right.$ dry weight) of the supplement, $D_{\mathrm{ffd}}$ and $\mathrm{D}_{\mathrm{sbd}}$ are the apparent digestibilities of dietary gross energy for the FF2 and SBF2 diets respectively, and $E_{s}$ and $E_{s b d}$ are the gross energy intakes from the SBF and the whole of the supplemented diet respectively. The apparent digestibility of dietary gross energies for the two diets were calculated as:

$$
\begin{aligned}
& \mathrm{D}_{\mathrm{rpd}}=1-\left(\mathrm{FE}_{\mathrm{rrd}} / \mathrm{E}_{\mathrm{rfd}}\right), \\
& \mathrm{D}_{\mathrm{shd}}=1-\left(\mathrm{FE}_{\mathrm{sbd}} / \mathrm{E}_{\mathrm{sbd}}\right)
\end{aligned}
$$

where $F E_{f f d}$ and $F E_{s b d}$ are the faecal energies lost to animals on the fibre-free and SBFsupplemented diets respectively, and $\mathrm{E}_{\mathrm{ffd}}$ and $\mathrm{E}_{\mathrm{sbd}}$ are the corresponding energy intakes on these diets. The values $\mathrm{E}_{\mathrm{rfd}}, \mathrm{E}_{\mathrm{sbd}}, \mathrm{FE}_{\mathrm{ffd}}$ and $\mathrm{FE}_{\mathrm{sbd}}$ were calculated as products of the measurement variables (heats of combustion and dry mass).

\section{Statistical analysis}

Unless otherwise indicated, the significance of differences between means was assessed by one-way analysis of variance followed by comparison with the least significant difference (LSD). For the comparison of crypt cell production rate, the significance of differences between slopes of regression lines was compared by means of a $t$ test utilizing pooled sums of squares. For the dietary energy balance study the two diets were compared using Student's unpaired $t$ test.

\section{RESULTS}

\section{Physiological study}

All the experimental diets were well accepted by the animals fed ad lib., with no evidence of aversion to SBF. The total food and water consumption and final body-weights of each group are shown in Table 2. Animals given guar gum had a lower food intake, higher water intake relative to food intake and lower final body-weight than the other groups. With food intake as the concomitant variable, an analysis of covariance indicated that after accounting for food intake effects, animals given guar gum and SBF had significantly lower body-weights $(P<0.05$; Table 2$)$. By contrast wheat bran was without any effect. The coefficient of covariance for final body-weight related to weight of ingested food was significant $(P<0.001)$, and was $0.37 \mathrm{~g}$ live weight $/ \mathrm{g}$ food intake.

As expected, all the fibre-supplemented diets led to a significant increase in output of both wet and dry faecal mass compared with animals given diet FF1 (fibre-free control diet). In order to make meaningful comparisons between groups, the faecal output of each caged pair of rats was normalized by expressing it relative to food intake ( $\mathrm{g}$ faeces/g dry food intake per $7 \mathrm{~d} \times 100$ ). The values are given in Table 3 . The highest intra-caecal $\mathrm{pH}$ occurred in the animals given diet FFl, and the lowest in the guar gum-fed rats. Wheat bran and both levels of SBF each produced intermediate intra-caecal $\mathrm{pH}$ values which were significantly less than those of the diet FF1 group (Table 3). 
Table 2. Total food and water intakes and final body-weights of rats fed on fibre-free or fibre-enriched diets

(Values are means with their standard errors of the means for five pairs of rats)

\begin{tabular}{|c|c|c|c|c|c|c|c|c|}
\hline \multirow[b]{3}{*}{ Dietary group* } & \multicolumn{4}{|c|}{ Body-wt (g/animal) } & \multirow{2}{*}{\multicolumn{2}{|c|}{$\begin{array}{l}\text { Food intake } \\
\text { (g/pair per } 28 \mathrm{~d})\end{array}$}} & \multirow{2}{*}{\multicolumn{2}{|c|}{$\begin{array}{l}\text { Water intake } \\
\text { (g/pair per } 28 \mathrm{~d})\end{array}$}} \\
\hline & \multicolumn{2}{|c|}{ Absolute } & \multicolumn{2}{|c|}{ Adjusted $\dagger$} & & & & \\
\hline & Mean & SEM & Mean & SEM & Mean & SEM & Mean & SEM \\
\hline Fibre-free & $373^{\mathrm{a}}$ & 13 & $373^{a}$ & 5 & $1254^{\mathrm{a}}$ & 30 & $1254^{\mathrm{a}}$ & 64 \\
\hline $\begin{array}{l}\text { Wheat bran } \\
(100 \mathrm{~g} / \mathrm{kg})\end{array}$ & $377^{\mathrm{a}}$ & 12 & $372^{\mathrm{ac}}$ & 3 & $1293^{\mathrm{a}}$ & 34 & $1353^{\mathrm{a}}$ & 60 \\
\hline $\begin{array}{l}\text { Guar gum } \\
(100 \mathrm{~g} / \mathrm{kg})\end{array}$ & $297^{b}$ & 29 & $347^{\mathrm{b}}$ & 9 & $1024^{\mathrm{b}}$ & 48 & $1290^{\mathrm{a}}$ & 25 \\
\hline $\begin{array}{l}\text { SBF } \\
(100 \mathrm{~g} / \mathrm{kg})\end{array}$ & $348^{\mathrm{a}}$ & 17 & $357^{\text {be }}$ & 5 & $1224^{\mathrm{a}}$ & 37 & $1288^{\mathrm{a}}$ & 57 \\
\hline
\end{tabular}

SBF, commercial sugar-beet fibre preparation (British Sugar plc).

a. b. " Values in a vertical column with different superscript letters were significantly different: $P<005$.

* For details of dietary treatments, see p. 188 and Table 1.

$\dagger$ Adjusted by analysis of covariance to food intakes equal to the mean intakes of the fibre-free-fed group.

Although there was no enlongation of the small intestine in animals given wheat bran compared with those fed on diet FF1, the guar gum-supplemented animals had significantly longer small intestines (Table 4). SBF did not appear to cause any significant lengthening of the small intestine. There was an enlargement of the caecum in all animals given fibre supplements, and this was most marked in those fed on guar gum. However, the moderate enlargement of the caecum and its contents seen in animals given SBF was not significantly different from that with wheat bran.

Fig. 1 shows the accumulation of blocked mitoses in ileal crypts in each of the experimental groups. Only the animals given guar gum showed evidence of a significant increase in the crypt-cell production rate relative to that of the FF1 group.

Plasma cholesterol levels of the FF1 group and the wheat-bran group showed no significant differences. The guar gum-fed animals had significantly lower plasma cholesterol levels than any of the other groups. The animals fed on the SBF1 diet also had lower cholesterol levels than the control and wheat bran-fed groups (Table 5).

The group-mean plasma cholesterol concentration (Table 5) showed a rank-order correlation of 1.0 with the group-mean absolute final body-weights (Table 2), and analysis of residuals of individual values from all the groups indicated that this relationship was close to statistical significance $(P=0 \cdot 065)$. However, the coefficient of covariance was low $(0.006$ (SD 0.003$) \mu \mathrm{mol}$ cholesterol $/ \mathrm{ml}$ plasma per $\mathrm{g}$ final body-weight) and this explained little of the variance $(r 0 \cdot 13)$. Therefore, the differences in plasma cholesterol concentration observed in the guar gum- and SBF-fed groups seem to be independent of the effects of these materials on body-weight. Moreover, there was no significant relationship between plasma cholesterol and food intake, since an analysis of residuals from the group-mean values indicated an increase in plasma cholesterol concentration of only 0.0013 (SD $0.0012) \mu \mathrm{mol} / \mathrm{ml}$ per $\mathrm{g}$ food intake over $28 \mathrm{~d}(P=0.53)$. Therefore, the effects of the supplements on plasma cholesterol were independent of any effects on food intake (adjusted values, Table 5).

Total plasma glucagon-like immunoreactivity was significantly greater in the animals fed on guar gum (481 (SEM 57)) than in all other groups, with bran-fed (182 (SEM 30)) and SBFfed (148 (SEM 17)) animals having significantly less plasma glucagon-like immunoreactivity than FF1-fed animals (221 (SEM 24)). 


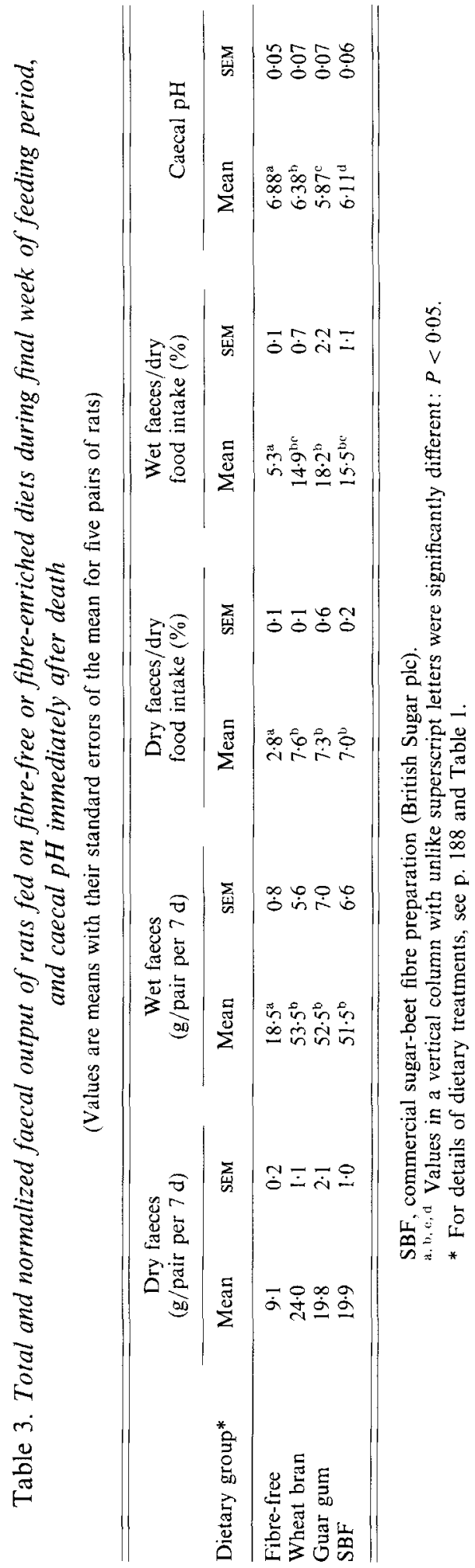


Table 4. Small intestinal length, caecal tissue weight and weight of caecal contents in rats fed on fibre-free or fibre-enriched diets

(Values are means with their standard errors of the mean for ten rats)

\begin{tabular}{|c|c|c|c|c|c|c|}
\hline \multirow[b]{2}{*}{ Dietary group* } & \multicolumn{2}{|c|}{$\begin{array}{l}\text { Small intestinal } \\
\text { length }(\mathrm{mm})\end{array}$} & \multicolumn{2}{|c|}{$\begin{array}{c}\text { Caecal tissue mass } \\
\text { (mg dry wt) }\end{array}$} & \multicolumn{2}{|c|}{$\begin{array}{l}\text { Caecal contents } \\
\text { (g wet wt) }\end{array}$} \\
\hline & Mean & SEM & Mean & SEM & Mean & SEM \\
\hline Fibre-free & $1200^{\mathrm{a}}$ & 20 & $211^{a}$ & 11 & $1 \cdot 46^{\mathrm{a}}$ & $0 \cdot 1$ \\
\hline Wheat bran & $1170^{\mathrm{a}}$ & 20 & $238^{\mathrm{ac}}$ & 11 & $1.82^{a}$ & $0 \cdot 3$ \\
\hline Guar gum & $1390^{\mathrm{h}}$ & 30 & $333^{\circ}$ & 13 & $4.89^{b}$ & $0 \cdot 3$ \\
\hline SBF & $1220^{\mathrm{a}}$ & 30 & $250^{\circ}$ & 17 & $2 \cdot 56^{\circ}$ & $0 \cdot 3$ \\
\hline
\end{tabular}

SBF, commercial sugar-beet fibre preparation (British Sugar plc).

a. $D, c$ Values in a vertical column with unlike superscript letters were significantly different: $P<0.05$.

* For details of dietary treatments, see p. 188 and Table 1.

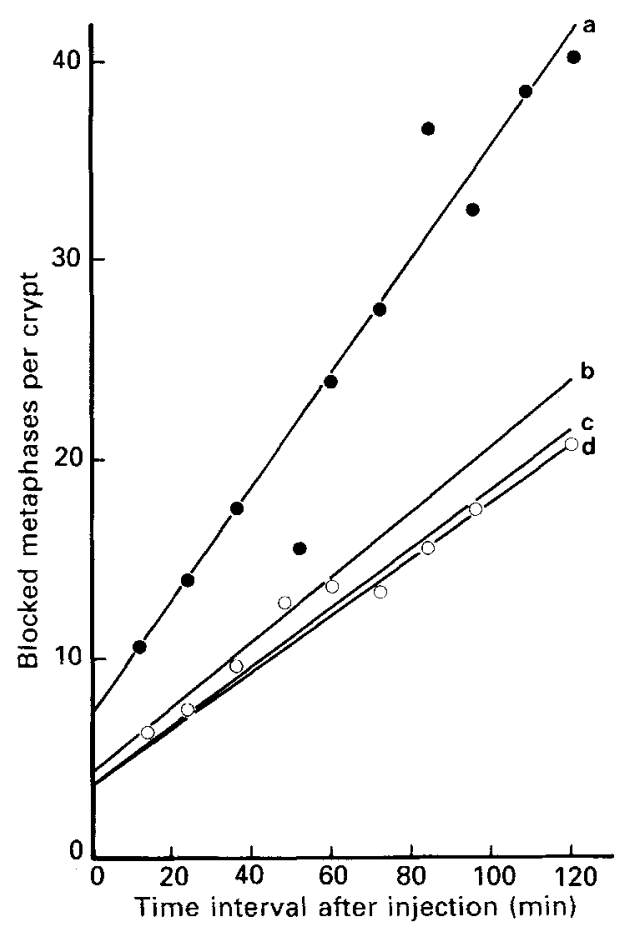

Fig. 1. Accumulation of blocked metaphases in ileal crypts of the rat after injection with the antimitotic drug vincristine. Regression lines are shown for (a) guar gum-supplemented ( $)$ and (c) sugar-beet-fibre-supplemented (O) diets respectively, and for clarity only these points are given; (b) and (d) are the regression lines for the fibrefree and wheat-bran-supplemented diets respectively. For details of dietary treatments, see p. 188 and Table 1.

\section{Digestible energy value}

On the basal diet FF2, animals grew from a mean prefed live weight of 152 (SEM 1) g to a mean weight of 208 (SEM 2) g. Growth was not different as a result of supplementations with SBF, the corresponding weights being 152 (SEM 1) g and 212 (SEM 3) g respectively.

The moisture content of the SBF was $120 \mathrm{~g} / \mathrm{kg}$ fresh weight and its heat of combustion was $17.64 \mathrm{~kJ} / \mathrm{g}$ dry matter. Moisture in the SBF2 diet was $62 \mathrm{~g} / \mathrm{kg}$ fresh weight and its heat of combustion was $19.85 \mathrm{~kJ} / \mathrm{g}$ dry weight. From these findings and the knowledge that 
Table 5. Serum cholesterol levels in rats fed on fibre-free or fibre-enriched diets over a 28 d period

(Values are means with their standard errors of the mean for ten rats)

\begin{tabular}{|c|c|c|c|c|}
\hline \multirow[b]{3}{*}{ Dietary group* } & \multicolumn{4}{|c|}{ Serum cholesterol $(\mu \mathrm{mol} / \mathrm{ml})$} \\
\hline & \multicolumn{2}{|c|}{ Absolute } & \multicolumn{2}{|c|}{ Adjusted $\dagger$} \\
\hline & Mean & SEM & Mean & SEM \\
\hline Fibre-free & $4 \cdot 1^{\mathrm{a}}$ & $0 \cdot 1$ & $4 \cdot 1^{\mathrm{a}}$ & $0 \cdot 1$ \\
\hline Wheat bran & $3 \cdot 9^{\mathrm{a}}$ & $0 \cdot 2$ & $3 \cdot 9^{\mathrm{a}}$ & 0.2 \\
\hline Guar gum & $2 \cdot 2^{\mathrm{h}}$ & $0 \cdot 1$ & $2 \cdot 4^{b}$ & $0 \cdot 1$ \\
\hline SBF & $3 \cdot 1$ & 0.2 & $3 \cdot 1^{\mathrm{c}}$ & $0 \cdot 2$ \\
\hline
\end{tabular}

$\mathrm{SBF}$, commercial sugar-beet fibre preparation (British Sugar plc).

$a, b, c$ Values in a vertical column with unlike superscript letters were significantly different: $P<0.05$.

* For details of dietary treatments, see p. 188 and Table 1.

+ Adjusted by analysis of covariance to food intakes equal to the mean intake of the fibre-free-fed group.

Table 6. Food and energy intake, faecal mass and energy, and digestibility of dietary energy in rats given fibre-free (FF2) or sugar-beet-fibre (SBF)-supplemented diets

(Values are means with their standard errors of the mean for ten rats per group)

\begin{tabular}{|c|c|c|c|c|}
\hline \multirow[t]{2}{*}{ Dietary group $\nmid \ldots$} & \multicolumn{2}{|c|}{ Unsupplemented FF2 } & \multicolumn{2}{|c|}{ Supplemented SBF } \\
\hline & Mean & SEM & Mean & SEM \\
\hline Food intake (g fresh wt $/ 28 \mathrm{~d}$ ) & $279 \cdot 8$ & 0.04 & $308 \cdot 0^{* *}$ & $0 \cdot 02$ \\
\hline Food intake (g dry wt $/ 28 \mathrm{~d}$ ) & $262 \cdot 7$ & $0 \cdot 04$ & $288 \cdot 9 * *$ & 0.02 \\
\hline Gross energy intake $(\mathrm{kJ} / 28 \mathrm{~d})$ & 5267 & 1 & $5735^{* *}$ & 1 \\
\hline Faecal mass (g dry wt $/ 28 \mathrm{~d}$ ) & $8 \cdot 2$ & $0 \cdot 7$ & $16 \cdot 7^{* *}$ & $1 \cdot 9$ \\
\hline Heat of combustion of faeces $(\mathrm{kJ} / \mathrm{g})$ & $15 \cdot 9$ & $2 \cdot 0$ & 17.9 & 0.8 \\
\hline Faecal energy (kJ/28 d) & 130 & 6 & $298^{* *}$ & 9 \\
\hline $\begin{array}{l}\text { Apparent digestibility of dietary } \\
\text { energy }\end{array}$ & $0 \cdot 977$ & $0-002$ & $0 \cdot 948^{* *}$ & 0.002 \\
\hline
\end{tabular}

Mean values were significantly different from those for FF2 group (Student's unpaired $t$ test): ${ }^{* *} P<0-01$.

$\uparrow$ For details of dietary treatment, see p. 188 and Table 1.

$100 \mathrm{~g}$ fresh weight of isolate was contained in each $1102.5 \mathrm{~g}$ fresh weight of diet SBF2 (Table 2), the gross energy fraction of diet SBF2 due to the isolate $\left(E_{s} / E_{\text {shd }}\right.$ in equation 2) was calculated to be $0.076 \mathrm{~kJ} / \mathrm{kJ}$ diet.

Animals fed on the SBF2 diet produced well-formed faeces enabling complete collections to be made. Food wastage was measured to be less than $0.1 \%$, a low value which was achieved because any slight spillage of food was weighed daily and an equal quantity of fresh food returned to the following day's feed.

Table 6 gives the food and energy intakes, faecal output, and the apparent digestibilities of gross dietary energies calculated for the present study. Supplementation of the basal diet (FF2) with the SBF elevated the dry bulk of faeces by a factor of 2.0 and energy in faeces by a factor of $2 \cdot 3$. The apparent digestibility of dietary gross energy decreased significantly $(P<0.001)$ from a value of 0.977 for the FF2 diet to 0.948 for the SBF-supplemented diet. The coefficients of variation for these derived values were small; 0.3 and $0.5 \%$ for the FF2 and the SBF2 diets respectively. 


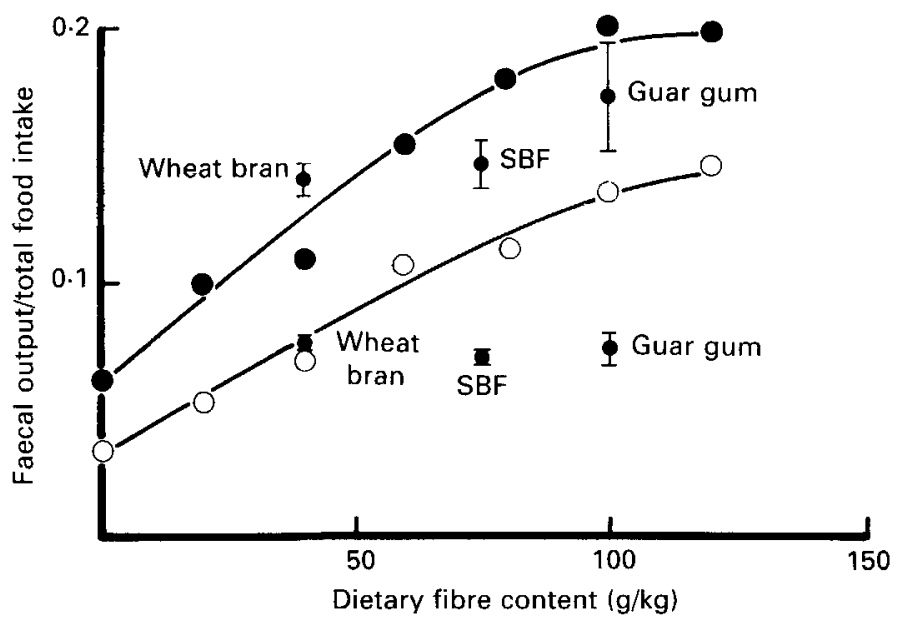

Fig. 2. The relationship between normalized faecal mass (faecal output/food intake) and cellulose (Solkafloc) content of the diet in rats ((O) wet mass; $(O)$ dry mass). Individual labelled points indicate the faecal mass produced on particular experimental diets containing a commercial sugar beet fibre (British Sugar plc; SBF), wheat bran or guar gum (for details of dietary treatments, see p. 188 and Table 1). The $x$ axis represents the dietary fibre (non-starch polysaccharide) content of each diet. Cellulose was used as a reference standard to compare bulking capacity of other materials.

The partial indigestibility of energy for the SBF, calculated using equation 2 , was 0.36 (SEM 0.03 ). This means that the equivalent of $36 \%$ of the gross energy supplied by the SBF was recovered in the faeces. The gross energy value of the SBF isolate was $17.64 \mathrm{~kJ} / \mathrm{g}$ dry matter. Therefore, the partial digestible energy value of the SBF, calculated from equation 1 , was 11.3 (SEM 0.5) $\mathrm{kJ}(2 \cdot 7$ (SEM 0.1) kcal)/g. These values refer to the SBF preparation as a whole.

Analysis of non-starch polysaccharides in SBF gives $0.75 \mathrm{~g} / \mathrm{g} \mathrm{SBF}$, the remaining combustible material being mostly lipid and protein. Consequently the gross energy fraction of the SBF2 diet due to non-starch polysaccharides was $0.57 \mathrm{~kJ} / \mathrm{kJ}$ diet. Using this value in place of 0.76 for $\mathrm{E}_{\mathrm{s}} / \mathrm{E}_{\mathrm{sbd}}$ in equation 2 gives a value for $S$ of 0.53 and a partial digestible energy value for the non-starch polysaccharides of $9 \cdot 1$ (SEM 0.5 ) $\mathrm{kJ}$ $(2 \cdot 2($ SEM $0 \cdot 1) \mathrm{kcal}) / \mathrm{g}$.

\section{DISCUSSION}

The present study provides evidence that the processed sugar-beet product combines some of the useful biological characteristics of insoluble, and soluble, forms of dietary fibre. The faecal bulking capacity of different sources of fibre depends on several factors. Poorly fermented materials add mass to the faeces and some non-starch polysaccharides appear also to increase the excretion of endogenous material. The amount excreted by individual animals depends partly on their total food intake, and this was taken into account by normalizing the data, as shown in Table 3 . These findings show that the $100 \mathrm{~g} / \mathrm{kg}$ dietary level of wheat bran, guar gum and SBF each gave similar increases in faecal bulk, measured on a dry-weight basis.

More insight into the significance of this observation is provided by Fig. 2. The curves in Fig. 2 were obtained in an earlier and separate study (I. T. Johnson and J. C. Brown, unpublished results) and show faecal mass normalized for food intake from animals given diets containing various levels of cellulose (Solkafloc). This material is amongst the most poorly fermented of non-starch polysaccharides (Van Soest, 1984), and the dry material has 
a dietary fibre count of virtually $100 \%$. Both SBF and wheat bran are complex materials containing smaller percentages of non-starch polysaccharides. To allow for this, in Fig. 2, the normalized faecal output values have been plotted against the appropriate non-starch polysaccharide content of the diet. Generally, materials giving points lying below the line relating dry faecal mass to cellulose intake must have been partially broken down and absorbed during transit through the gut by microbial fermentation. The values for dry faecal mass in animals given SBF and guar gum fall well below the line for cellulose in Fig. 2. Guar gum is known to be efficiently fermented by colonic microflora in the rat (Wyatt et al. 1988); the increased faecal output compared with animals fed on a fibre-free diet is presumably due to bacterial mass. In terms of wet mass, SBF gave faecal weights close to those expected for the cellulose, and wheat bran gave values a little greater. These findings (Fig. 2) are consistent with the non-starch polysaccharide constituents of SBF being fermented more readily than cellulose during transit through the large bowel.

Fermentation of carbohydrate in the large bowel leads to the release of volatile fatty acids, and hence to acidification of the bowel contents. Animals given cellulose characteristically have a caecal pH slightly less acid than that of control animals given a fibre-free diet (Johnson et al. 1988). In the present study all the experimental diets gave rise to small but significant reductions in the $\mathrm{pH}$ of the caecal contents, relative to that of the fibre-free control group. The mean of the measured caecal $\mathrm{pH}$ of the SBF-fed group was slightly lower than that of the wheat-bran group (Table 3); this is again consistent with the somewhat higher fermentable fibre content of SBF compared with wheat bran.

There were relatively minor changes in the morphology of the intestinal tract in the experimental groups other than the guar gum-fed animals. The small intestinal length of the group of animals given guar gum was significantly greater than that of all the other groups. This phenomenon is characteristic of resistant polysaccharides which are both soluble and highly viscous (Elsenhans et al. 1981; Johnson \& Gee, 1986). The caecum was also enlarged, both in terms of contents and tissue mass, in the guar gum-fed rats. Smaller increases also occurred in the animals given SBF. As observed in previous studies (Johnson \& Gee, 1986), there was a significant increase in cell proliferation in the distal ileum of the guar gum-fed rats, but there was no effect in any other group.

Enteroglucagon is a peptide released by specialized cells of the distal intestinal mucosa in response to nutrients, and perhaps also fermentation products, in the lumen (Riecken \& Gregor, 1985). It forms the major component of glucagon-like immunoreactivity in recently fed rats (Johnson et al. 1988). Circulating levels of enteroglucagon are raised following a meal, both in experimental animals and man, and the amounts released depend to some extent on the dietary fibre content of the diet. The enteroglucagon level seems to be a physiological indicator of soluble non-absorbable polysaccharides which retard nutrient absorption, or those such as gum arabic which are rapidly fermented in the gut (Johnson et al. 1988). Only guar gum led to a significant increase in glucagon-like immunoreactivity relative to the fibre-free group in the present study. The post-prandial enteroglucagon response in the animals given SBF is consistent with the possibility that the soluble fraction of this material is not sufficiently viscous to give rise to increased nutrient concentrations in the distal ileum.

It is well-established that some forms of dietary fibre have significant hypocholesterolaemic effects in experimental animals and man, and it is generally the soluble components which exert this effect (Judd \& Truswell, 1982). In the present study serum cholesterol was over $40 \%$ lower in animals given guar gum compared with controls, whilst wheat bran had no effect. Animals given diet SBFI also had lower serum cholesterol levels than both the controls and the wheat bran-fed group. This effect was independent of differences in food intake and body-weight. 
The mechanism by which SBF exerts its hypocholesterolaemic action in the rat is unclear. There was no evidence of changes in gastrointestinal morphology, cell proliferation or enteroglucagon output which accompany the ingestion of guar gum, and other viscous polysaccharides having hypocholesterolaemic properties. Possibly the products of fermentation of the soluble, but low-viscosity components of SBF act directly on endogenous cholesterol metabolism, as suggested by Anderson \& Bridges (1981).

In the present paper we have continued to make the important distinction between partial digestibility and apparent digestibility or energy value, as explained in detail elsewhere (Kleiber, 1975; Livesey, 1990; Livesey et al. 1990). The use of partial rather than apparent digestible energy values for food energy calculations was recommended by a recent workshop on the topic (Livesey, 1989a). In the present study, supplementation of the basal diet with SBF led to a rise in the loss of energy to faeces which was not much greater than the rise in the dry mass of faeces produced, these values being 2-3-fold and 2-fold respectively. The similarity of these two values is suggestive of the SBF not having very large effects on losses of protein and fat to the faeces, which are of a higher energy density $(23.6$ and $39.6 \mathrm{~kJ} / \mathrm{g}$ respectively) than either the isolate $(17.64 \mathrm{~kJ} / \mathrm{g}$ ) or of the faeces produced on the basal diet $(15.9 \mathrm{~kJ} / \mathrm{g})$.

Elevated faecal protein and fat losses did occur with the unavailable carbohydrate contained within the food matrix of the British types of diet fed to humans by Southgate $\&$ Durnin (1970). It is of significance that it was the elevated losses of protein and fat to faeces which resulted in their observing a partial indigestibility of energy close to unity for unavailable carbohydrate in the UK diet, and which led them to infer a partial digestible energy value close to zero.

More recent analysis of the current evidence (Livesey, 1988, 1990) suggests that for a large number of diets with unavailable carbohydrate from mixed sources or from fruit and vegetables, but not from whole-grain cereals, the digestible energy value of unavailable carbohydrate in the human diet is about $8.4 \mathrm{~kJ}(2 \mathrm{kcal}) / \mathrm{g}$, midway between that implied by the classical Atwater factors for carbohydrate $(16.7 \mathrm{~kJ}(4 \mathrm{kcal}) / \mathrm{g})$, and that currently accepted in the UK $(0 \mathrm{~kJ} / \mathrm{g})$. The present findings, which suggest a partial digestible energy value of $9 \cdot 1 \mathrm{~kJ}(2 \cdot 2 \mathrm{kcal}) / \mathrm{g}$, is consistent with this. Moreover, the value $9 \cdot 1 \mathrm{~kJ}(2.2 \mathrm{kcal}) / \mathrm{g}$ is less than the apparent digestible energy value of sugar-beet fibre which is estimated from its apparent digestibility, 0.68 (Nyman \& Asp, 1982), and its heat of combustion $(17.2 \mathrm{~kJ} / \mathrm{g})$, which gives $11.7 \mathrm{~kJ}(2.79 \mathrm{kcal}) / \mathrm{g}$. That partial digestible energy values are lower than apparent digestible energy values for unavailable carbohydrates is consistently observed (Livesey, 1990) and is due to microbial material lost to faeces after growth on the fermentable unavailable carbohydrate.

It is now thought that the efficiency of conversion in vivo of gross energy for fully fermented non-starch polysaccharides to faecal energy is, on average, about $0 \cdot 3$ in man and the rat, in the absence of 'associative effects' such as nutrient malabsorption (Livesey, 1990). On this basis, an estimate of digestible energy value of unavailable carbohydrate has been suggested to be approximately $17.2 \times 0.7 \alpha \mathrm{kJ} / \mathrm{g}$, where $\alpha$ is the apparent digestibility of the unavailable carbohydrate. It is interesting to note that the apparent digestibility of the sugar-beet 'fibre' determined by Nyman \& Asp (1982) to be 0.68 (including lignin) corresponds to an estimated digestible energy value of $17.2 \times 0.68 \times 0.7$, equal to $8.2 \mathrm{~kJ}$ (approximately $2 \mathrm{kcal}$ ) $/ \mathrm{g}$. This value is not significantly different from that obtained by dietary energy balance in the present study, and both are similar to that estimated as an average value for unavailable carbohydrate in the majority of human diets, where the average apparent digestibility of unavailable carbohydrate is also close to $0 \cdot 70$ (Livesey, 1990). Consistent with observations on faecal bulking in Fig. 2, the partial digestible energy value for the non-starch polysaccharide in $\mathrm{SBF}(9 \cdot 1 \mathrm{~kJ}(2.2 \mathrm{kcal}) / \mathrm{g})$ falls between that 
estimated for Solkafloc $(1.7 \mathrm{~kJ}(0.4 \mathrm{kcal}) / \mathrm{g})$ and that for guar gum $(10.1 \mathrm{~kJ}(2.4 \mathrm{kcal}) / \mathrm{g})$, recently determined by Davies et al. (1987).

Sugar-beet fibre is evidently one of a few sources of dietary fibre which are capable of providing both faecal bulk and some of the metabolic effects which are characteristic of much less palatable materials such as pectin and legume gums. Further investigations will be necessary to determine whether these effects occur in humans regularly consuming SBF. Consistent with this are the recent results of Morgan et al. (1988), showing a significant reduction in total plasma cholesterol levels in human subjects after $14 \mathrm{~d}$ dietary supplementation with SBF.

The authors thank British Sugar plc for financial support.

\section{REFERENCES}

Anderson, J. W. \& Bridges, S. R. (1981). Plant fibre metabolites alter hepatic glucose and lipid metabolism. Diabetes 30, 133A.

Anderson, J. W., Story, L., Sieling, B., Chen, W. L., Petro, M. S. \& Story, J. (1984). Hypocholesterolemic effects of oat-bran or bean intake for hypercholesterolemic men. American Journal of Clinical Nutrition 40, 1146-1155.

Clarke, R. M. (1970). Mucosal architecture and epithelial cell production in the small intestine of the albino rat. Journal of Anatomy 107, 519-529.

Davies, I. R., Johnson, I. T. \& Livesey, G. (1987). Food energy values of dietary fibre components and decreased deposition of body fat. International Journal of Obesity 11, Suppl. 1, 101-105.

Elsenhans, B., Blume, R. \& Caspary, W. F. (1981). Long-term feeding of unavailable carbohydrate gelling agents. Influence of dietary concentration and microbiological degradation on adaptive responses in the rat. American Journal of Clinical Nutrition 34, 1837-1848.

Englyst, H. N. \& Cummings, J. H. (1984). Simplified method for the measurement of total non-starch polysaccharides by gas - liquid chromatography of constituent sugars as alditol acetates. Analyst 109, 937-942.

Findlay, J. M., Mitchell, W. D., Smith, A. N., Anderson, A. J. B. \& Eastwood, M. A. (1974). Effects of unprocessed wheat bran on colonic function in normal subjects and in diverticular disease. Lancet $\mathbf{i}, 146-149$.

Jenkins, D. J. A., Wolever, T. M. S., Leeds, A. R., Gassull, M. A., Haisman, P., Dilawari, J., Goff, D. U., Metz, G. L. \& Alberti, K. G. M. M. (1978). Dietary fibres, fibre analogues and glucose tolerance: importance of viscosity. British Medical Journal i, 1392-1394.

Johnson, I. T. \& Gee, J. M. (1986). Gastrointestinal adaption in response to soluble non-available polysaccharides in the rat. British Journal of Nutrition 55, 497-505.

Johnson, I. T., Gee, J. M. \& Brown, J. C. (1988). Plasma enteroglucagon and small bowel cytokinetics in rats fed soluble nonstarch polysaccharides. American Journal of Clinical Nutrition 47, 1004-1009.

Judd, P. A. \& Truswell, A. S. (1982). Comparison of the effects of high- and low-methoxy pectins on blood and faecal lipids in man. British Journal of Nutrition 48, 451-458.

Kleiber, M. (1975). The Fire of Life: An Introduction to Animal Energetics, pp. 259-271. Huntington, New York: Robert E. Kriegar Publishing Co.

Livesey, G. (1988). Energy from foods - old values and new perspectives. British Nutrition Foundation Bulletin 13, 9-28.

Livesey, G. (1989a). Energy and complex carbohydrates: workshop report. In Nutrient Availability: Chemical and Biological Aspects, pp. 385-387 [D. A. J. Southgate, I. T. Johnson and G. R. Fenwick, editors]. Cambridge: Royal Society of Chemistry.

Livesey, G. $(1989 \mathrm{~b})$. Procedure for calculating the digestible and metabolisable energy values of food components making a small contribution to dietary intake. Journal of the Science of Food and Agriculture 48, 475-481.

Livesey, G. (1990). The energy values of unavailable carbohydrates and diets: an enquiry and analysis. American Journal of Clinical Nutrition (In the Press).

Livesey, G., Davies, I. R., Brown, J. C., Faulks, R. M. \& Southon, S. (1990). Energy balance and energy value of $\alpha$-amylase (EC 3.2.1.1)-resistant maize and pea (Pisum sativum) starches in the rat. British Journal of Nutrition 63, 467-480.

Morgan, L. M., Tredger, J. A., Williams, C. A. \& Marks, V. (1988). Effects of sugar beet fibre on glucose tolerance and circulating cholesterol levels. Proceedings of the Nutrition Society 47, 185A.

Nyman, M. \& Asp, N.-G. (1982). Fermentation of dietary fibre components in the rat intestinal tract. British Journal of Nutrition 47, 357-366.

Riecken, E. O.\& Gregor, M. (1985). Glucagon and small bowel mucosa. Scandinavian Journal of Gastroenterology 20, Suppl. 112, 30-40.

Selvendran, R. R., Stevens, B. J. H. \& DuPont, M. S. (1987). Dietary fibre: chemistry, analysis and properties. Advances in Food Research 31, 117-209. 
Southgate, D. A. T. \& Durnin, J. V. G. A. (1970). Caloric conversion factors. An experimental reassessment of the factors used in the calculation of the energy value of human diets. British Journal of Nutrition 24, 517-535.

Trowell, H., Southgate, D. A. T., Wolever, T. M. S., Leeds, A. R., Gassull, M. A. \& Jenkins, D. J. A. (1976). Dietary fibre redefined. Lancet i, 1967.

Van Soest, P. J. (1984). Some physical characteristics of dietary fibres and their influence on the microbial ecology of the human colon. Proceedings of the Nutrition Society 43, 25-33.

Wyatt, G. M., Horn, N., Gee, J. M. \& Johnson, I. T. (1988). Intestinal microflora and gastrointestinal adaptation in the rat in response to non-digestible dietary polysaccharides. British Journal of Nutrition 60, 197-207. 